\title{
PRACTICAL APPLICATION OF THE GEOGRAPHIC RESEARCH OF A FAMILY: A CASE STUDY
}

\section{PRAKTYCZNE ZASTOSOWANIE BADAŃ GENOGRAFICZNYCH: STUDIUM PRZYPADKU RODZINY}

\author{
Oleksandr V. Oliynyk ${ }^{1(A, B, C, D, E)}$, Kseniya O. Oliynyk ${ }^{1(E)}$ \\ ${ }^{1}$ I. Horbachevsky Ternopil State Medical University, Ukraine
}

Authors' contribution Wkład autorów: A. Study design/planning zaplanowanie badań B. Data collection/entry zebranie danych

C. Data analysis/statistics dane - analiza i statystyki D. Data interpretation interpretacja danych

E. Preparation of manuscript przygotowanie artykułu F. Literature analysis/search wyszukiwanie i analiza literatury G. Funds collection zebranie funduszy
Tables: 0

Figures: 5

References: 7

Submitted: 2017 Apr 30

Accepted: 2017 May 21

\section{Summary}

Background. A combined genetic and geographic analysis facilitates the discovery of one's ethnic background by studying the closest ancestors and those who lived thousands of years ago. The following article describes a practical application of doing geographic research on a person's history. The objective of the study is to demonstrate the capacity of genetic and geographic analysis in the identification of the ethnic background of one of the article's coauthors.

Material and methods. A combined analysis of genetic alleles and geographic location was performed. A buccal smear from the inside of the cheek was done for a further study that was performed in Medical Genomix laboratory, USA. The material was collected at Mother and Child laboratory, Kyiv.

Results. The genetic profile of the examined person was presented. The available alleles, detected by markers, are specific enough to a particular historical group (nation), which enables determining the percentage of ancestors of an individual under study in a particular region.

Conclusions. Combined genetic and geographic research may serve both as a source of information on the ethnic origin of a particular person and as a tool while studying some places and geographic locations.

Keywords: genetic alleles, geographic analysis, the Genographic Project

\section{Streszczenie}

Wprowadzenie. Połączona analiza genetyczna i geograficzna ułatwia odkrycie etnicznego pochodzenia najbliższych przodków i tych, którzy żyli tysiące lat temu. Poniższy artykuł opisuje praktyczne zastosowanie badań genograficznych w prześledzeniu historii rodziny. Celem badania jest wykazanie zdolności połączonych badań genetycznych i geograficznych w identyfikacji pochodzenia etnicznego jednego $\mathrm{z}$ współautorów artykułu.

Materiał i metody. Przeprowadzono połączoną analizę alleli genetycznych i położenia geograficznego współautorki artykułu. Pobrano wy maz z wnętrza policzka w celu dalszego badania materiału genetycznego, które przeprowadzono w laboratorium medycznym Genomix w USA. Materiał pobrano w Laboratorium Matki i Dziecka w Kijowie.

Wyniki. Przedstawiono profil genetyczny badanej osoby. Aby zidentyfikować allele, użyto markerów, które są na tyle specyficzne dla danej grupy osób, że umożliwiają określenie dalekiego i etnicznego pochodzenia przodków badanej jednostki w danym regionie.

Wnioski. Połączenie badań genetycznych i geograficznych może służyć zarówno uzyskaniu informacji o pochodzeniu etnicznym osoby, jak i narzędzie do badań miejsc i lokalizacji geograficznych.

Słowa kluczowe: allele genetyczne, analiza geograficzna, projekt genograficzny

\section{Introduction}

Who were our ancestors? Where do we come from? Most people can track their family tree only 3-4 generations back. A genetic analysis is expected to provide a proper answer to the above and similar questions.

Since 2005, a major international Genographic Project has been realised [1, 2], It has studied mitochondrial and Y-chromosome DNA variability among populations of different Earth zones for the purpose of composing a detailed genetic atlas of peoples of the world. The project is funded by the American Geographical Society, with the budget exceeding $\$ 40$ million. The project procedure involves collecting genetic material, by giving preference to the natives of a particular region. By now, 12 years after the project started, about 700 thousand DNA samples have been collected, and 11 GP centres are working permanently throughout the world.

Oliynyk OV, Oliynyk KO. Practical application of the geographic research of a family: a case study. Health Prob Civil. 2017; 11(3): 300-305. DOI: https://doi.org/10.5114/hpc.2017.69030.

Address for correspondence / Adres korespondencyjny: Oleksandr V. Oliynyk, I. Horbachevsky Ternopil State Medical University, m.Voli, 1, Ternopil, 46001, Ukraine, e-mail: alexanderoliynyk8@gmail.com, phone: +380 352524492

Copyright: (C) 2017 Pope John Paul II State School of Higher Education in Biała Podlaska, Oleksandr V. Oliynyk, Kseniya O. Oliynyk. This is an Open Access journal, all articles are distributed under the terms of the Creative Commons Attribution-NonCommercial-ShareAlike 4.0 International (CC BY-NC-SA 4.0) License (http:// creativecommons.org/licenses/by-nc-sa/4.0/), allowing third parties to copy and redistribute the material in any medium or format and to remix, transform, and build upon the material, provided the original work is properly cited and states its license. 
The human DNA is 99.9 percent identical to all people. The remaining 0.1 percent is the source of individual differences. It is due to a random DNA change (mutation) that occurred at a functional DNA site. This modification is passed on to the descendants. By comparing specific DNA sites (marker genes) in different population groups, one can use the data for an ethnic identification of a particular person.

If a population group migrates or lives in geographic isolation, there is no genetic exchange with another group, and each of these groups acquires a peculiar set of mutations. If a human possesses a set of mutations typical of a particular nation, this may be the evidence of his/her belonging to a specific nation. Genetic mutations are not only the index of family belonging, but they also inform about one's ethnic community. Thus, the study of variations and their occurrence enables discerning separate branches of the human family tree.

Further, combined genetic and geographic analysis makes it possible for a person to discover belonging to an ethnic group of his/her nearest ancestors and those who lived thousands of years ago. The objective of the study of the following paper is to demonstrate the capacity of genetic and geographic research in the identification of Kseniya Oliynyk's ethnic origin, the co-author of the article. What urged the authors to do the research was the death of several of her family ancestors in the world wars and lack of information about their origin.

\section{Material and methods}

A combined genetic alleles and geographic location analysis was done. Kseniya Oliynyk's genetic sample was taken; a buccal smear from the inside of the cheek for further study that was performed in the DNA Tribes laboratory, USA [3]. The material was collected at Mother and Child laboratory, Kyiv. The amplification of DNA was performed by polymerase chain reaction $[4,5]$. The Biometra TAdvanced thermal cycler [6] was used as well as Oligonucleotide Selection Program [7], a computer programme for selection of oligonucleotide primers for polymerase chain reactions.

\section{Results}

The genetic and geographic research consisted of 4 parts: A, B, C, D. Part A: Autosomal STR Profile: the genetic profile of a person includes the values of 26 genetic markers distributed throughout autosomal chromosomes. At each locus, the person has two values: one allele inherited from the father and the other one inherited from the mother, which together constitute a total of 52 dimensions that are used to compute geographic ancestry. 175 genetic markers of 23 chromosome pairs are used to determine the percentage of each group in the human genome. The available alleles, detected by these markers, are specific enough to a particular historical group (nation/population), which makes it possible to determine the percentage of ancestors of the studied individual with regard to the regions they come from.

Part B: Native Population Match: These results list one's Top 20 matches in a database of 964 native populations that have experienced minimal movement and admixture in modern history, i.e. approximately the last 500 years). DNA matches do not necessarily suggest a recent family ancestor from each listed country but can express the genetic traces of more ancient relationships between populations through shared origins, migrations, and long-term trade contacts in each part of the world. For people with mixed ancestry, DNA matches can also identify communities where similar mixes have taken place (such as native populations located near former trade and migration routes between continents).

Part C: Global Population Match: These results list one's Top 20 matches in the database of 1,255 global populations, including native peoples as well as modern communities that have mixed and / or migrated around the world within the past 500 years. Matches with diasporic populations can express genetic material shared with one or more of the ancestral source populations for that modern ethnic group. For instance, DNA matches in Latin America can show European, Native American, and / or related African ancestry shared with these current populations. For people of mixed descent, these matches can also indicate the populations where similar mixes have taken place.

Part D: The World Region Match: Ancestry from each part of the world is most clearly expressed by one's regional DNA match scores in Part D. This comprehensive world region analysis complements more limited Part B - C comparisons to individual samples in a person's database (typically composed of 100-200 people each). Each of these world regions is a genetic cluster that is a product of long-term patterns of migration and settlements over several millennia. This part of the study deals with ancestors who lived a few thousand years ago. Besides, it contains a "triangular" graph with a percentage ratio of each historical group in the genome of a researched individual, thus presenting the picture of his/her geographic origin: Europe (Northern, Southern), Middle East, Indian subcontinent (India, Pakistan, Sri Lanka), Eastern Asian group (Japan, China, Mongolia, Korea) South-eastern group (Philippines, Malaysia, Australia, Oceania), African group (Nigeria, Congo etc.) 
Part A. Allele analysis:

\begin{tabular}{|c|c|c|}
\hline Locus & Allele 1 & Allele 2 \\
\hline D3S1358 & 15 & 18 \\
\hline$v W A$ & 14 & 16 \\
\hline D165539 & 10 & 12 \\
\hline CSFIPO & 10 & 12 \\
\hline TPOX & 10 & 11 \\
\hline DsS1179 & 10 & 15 \\
\hline D21S11 & 29 & 30.2 \\
\hline D18S51 & 15 & 16 \\
\hline$D 2 S 441$ & 11 & 14 \\
\hline D19S433 & 14 & \\
\hline THO1 & 9 & 9.3 \\
\hline$F G A$ & 22 & 23 \\
\hline D22S1045 & 17 & \\
\hline D5Ss1s & 11 & 12 \\
\hline D135317 & 8 & 11 \\
\hline$D 75820$ & 10 & \\
\hline SE33 & 28.2 & 29.2 \\
\hline$D 10 S 1248$ & 14 & 15 \\
\hline D1S1656 & 12 & 19.3 \\
\hline D12S391 & 22 & \\
\hline D2S1338 & 23 & 24 \\
\hline $\boldsymbol{L P L}$ & 10 & 12 \\
\hline$F 13 B$ & 6 & 8 \\
\hline F13AO1 & 3.2 & 6 \\
\hline Penta D & 11 & 12 \\
\hline Penta C & 13 & 14 \\
\hline Penta $E$ & 7 & 14 \\
\hline
\end{tabular}

Figure 1. Part A. Allele analysis

The family's alleles are shared by people in the following regions:

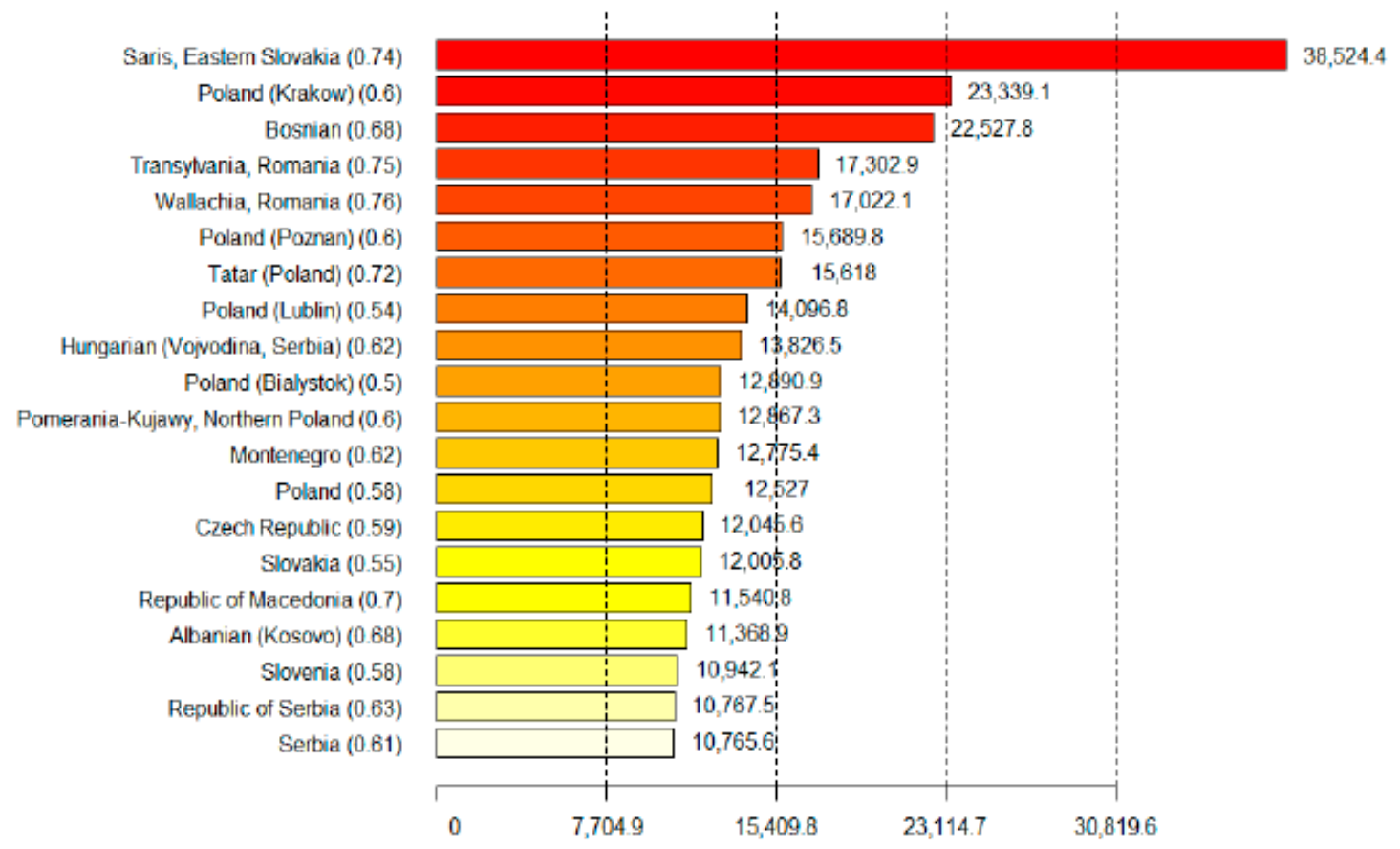

Figure 2. Regions in which Part A. alleles are shared

The figures on the right indicate how likely the person's chances are to belong to the group in a particular locality as opposed to some others. Thus, the figure 38524 means that the examined person is 38524 times more likely to be Slovak than any other nationality. Besides, in the town of Šariš, this gene is found in $74 \%$ of the residents. As for the ancestors who lived 500 years ago, the analysis reads as follows: 


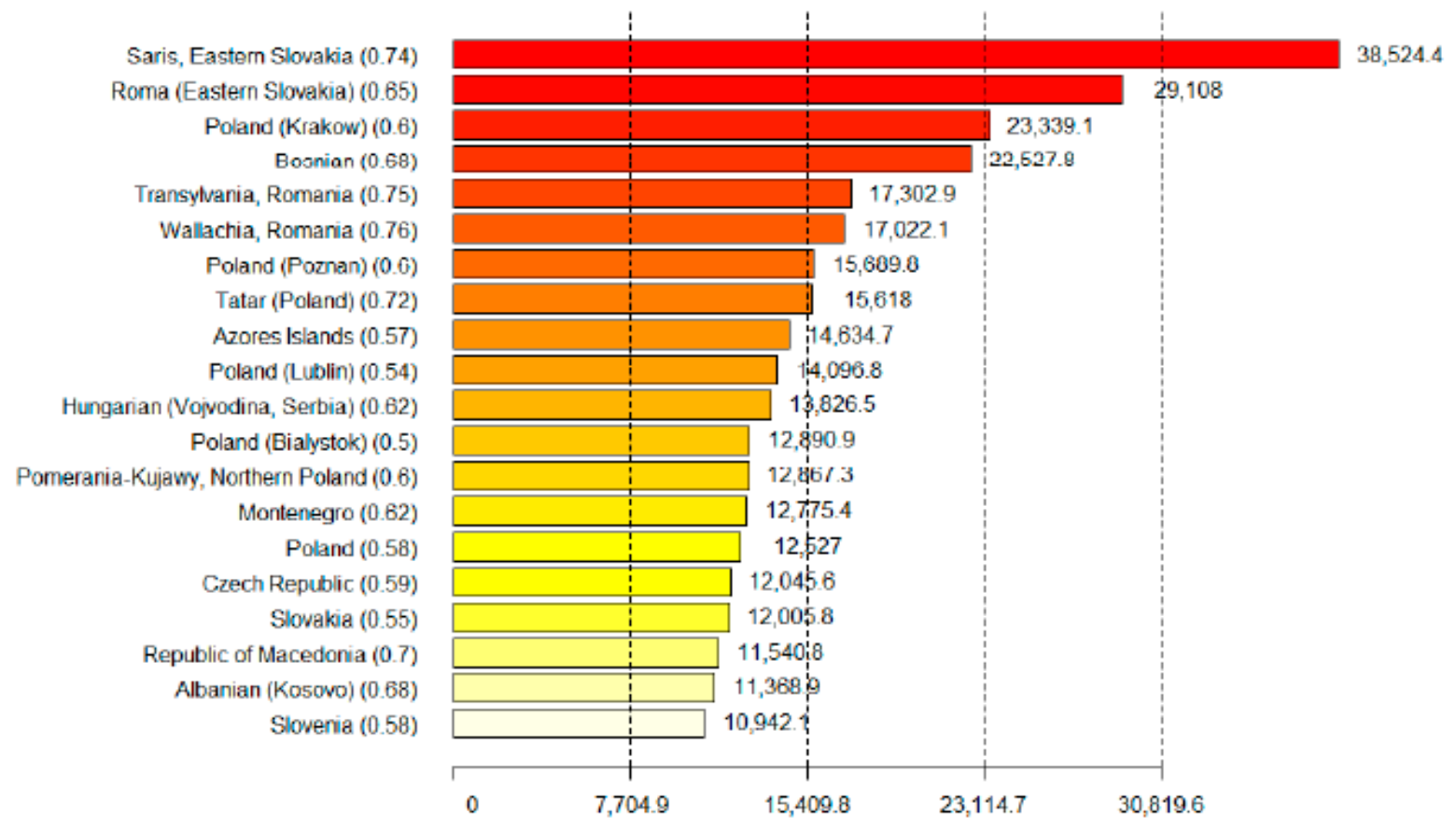

Figure 3. Results list of the global population investigation

This part of the research confirms the previously discussed data: Kseniya's relatives came mainly from Slovakia, Poland and Balkans. Graphically, the results can be mapped as follows:

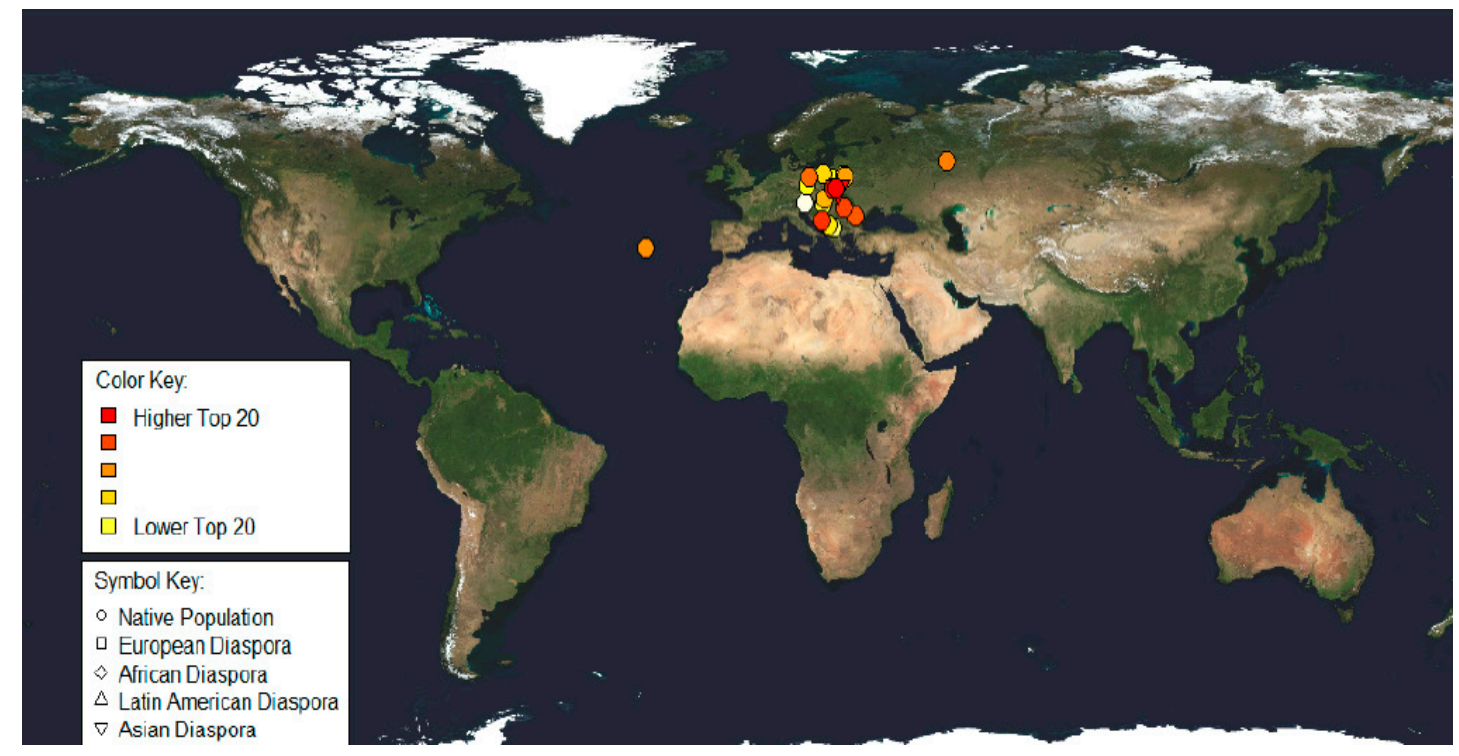

Figure 4. Map indicating the research results of the family's global ancestry

One finding turned out to be especially surprising. One ancestor came from the Azores but there was no information on it in the family archive.

The data on the remote ancestors who lived a few thousand years ago can be mapped as follows: 


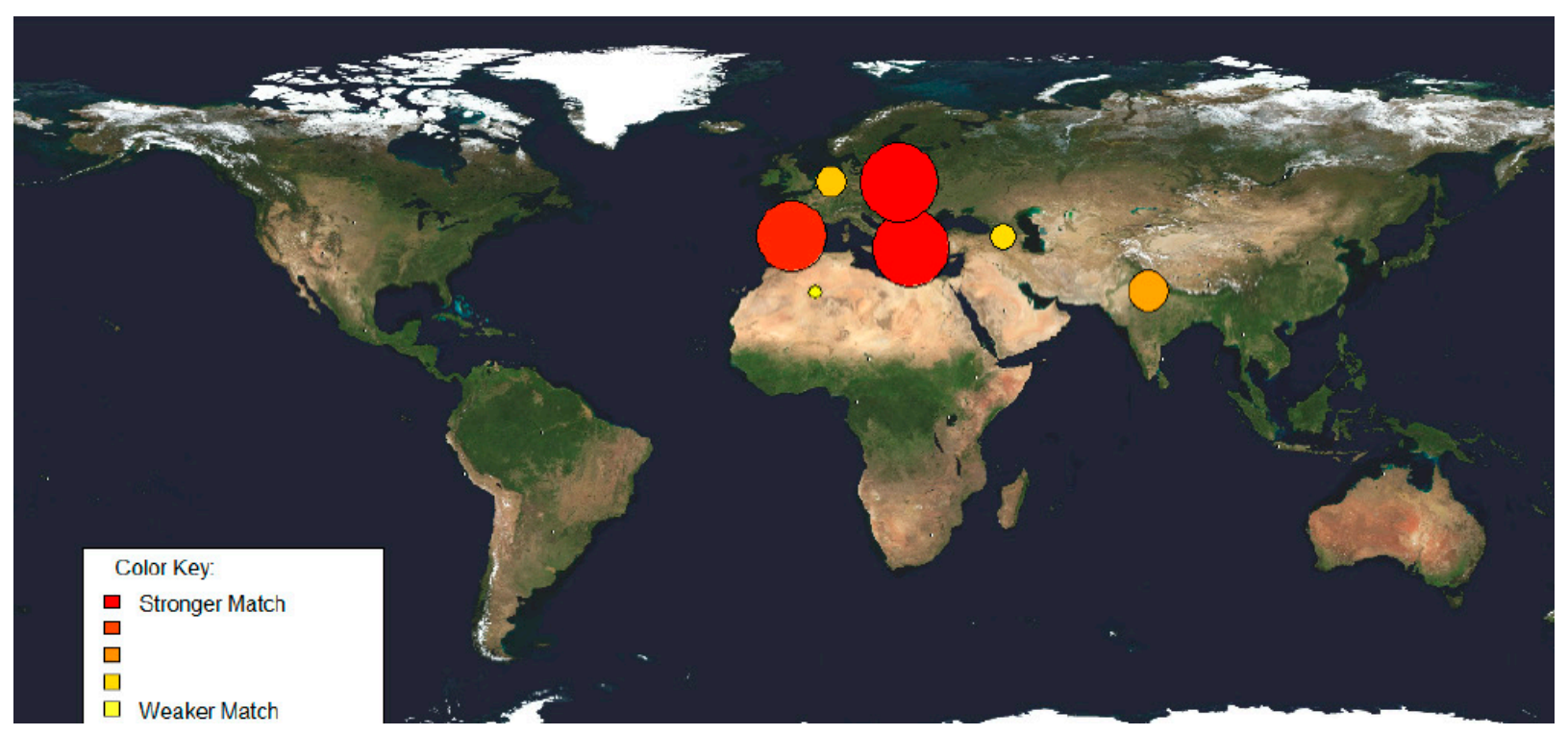

Figure 5. Map presenting the results of the family's ancestry location

\section{Discussion}

To determine the role of the research in the national identity of Kseniya Oliynyk's forefathers, we present information on the nationality of her ancestors four generations back:

\begin{tabular}{|c|c|c|c|c|c|c|c|}
\hline Pole & Romanian & $\begin{array}{c}\text { Ukrainian? } \\
\text { Russian? }\end{array}$ & German & Pole & Pole & Russian & Russian \\
\hline father & mother & father & mother & father & mother & father & mother \\
\hline \multicolumn{2}{|c|}{ grandmother } & \multicolumn{2}{|c|}{ grandfather } & \multicolumn{2}{c|}{ grandfather } \\
\hline \multicolumn{2}{|r}{ father } \\
\hline
\end{tabular}

What is most amazing in the findings is the lack of Russian and Ukrainian alleles in the investigated case, which is probably because Kseniya Oliynyk's mother's father was born in the woodland village of Budogoshch, Novgorod Region, Russia. However, it turned out that in the $18^{\text {th }}$ century the village had been settled by refugees from Polish town Bydgoszcz. The village inhabitants must have lived in isolation, without mixing with the peasants from the surrounding communities. This may account for the presence of northern Polish genes in the analysis. Another great-grandfather was born in Dnipropetrovsk Region. He had been missing in action, and Kseniya's father never saw him. Besides, little was known about his family. It appeared that the inhabitants of the district in which he lived had resettled from Serbia in the $19^{\text {th }}$ century. This was less surprising as one of the largest Serbian communities in Ukraine today lives in Dnipropetrovsk Region. This accounts for numerous traces of Serbs, Montenegrins and Bosnians in the area. All the other data confirmed the information that was found in the family archive, except for the one concerning the ancestor coming from the Azores. Who he was and whether he represented mother or father line in the family remains unclear. Besides, Kseniya shared a small number of genes with Slovak gypsies. The alleles from India and Mesopotamia were found in parts C and D. Therefrom, the gypsies must have come to Europe from these territories. Besides, some African genes were found in the remote ancestors. They were found in most persons and are very stable.

\section{Conclusion}

As the presented analysis shows, genetic and geographic research may serve both as a source of information on the ethnic origin of a particular person and a tool in doing some historical study of certain geographic places and localities. 


\section{References:}

1. The Genographic Project by National Geographic - Human Migration. [cited 2017 May 01]. Available from: www.genographic.nationalgeographic.com.

2. Basics of DNA Forensics Techniques - Explore DNA. [cited 2017 May 01]. Available from: www.exploredna. co.uk.

3. DNA Tribes ${ }^{\mathrm{TM}}$ Genetic Ancestry Analysis. [cited 2017 May 01]. Available from: www.dnatribes.com/.

4. Weier HU, Gray JW. A programmable system to perform the polymerase chain reaction. DNA. 1988; 7(6): 441-7.

5. Higgins James A, Nasarabadi Shanavaz, Karns Jeffrey S. A handheld real time thermal cycler for bacterial pathogen detection. Biosensors and Bioelectronics. 2003; 18 (9): 1115-1123.

6. The Most «Advanced» Thermal Cycler Yet - Get InformedGet Informed. [cited 2017 May 01]. Available from: www.labrepco.com/get-informed/.../biometra-thermal-cycler.

7. Hillier L, Green P. OSP: a computer program for choosing PCR and DNA sequencing primers. PCR Methods Appl. 2011; Nov.1 (2):124-8. 